\title{
A proposal for the evaluation of the bioeconomic efficiency of beef cattle production systems
}

\author{
Pedro Rocha Marques ${ }^{1}$, Vanessa Peripolli ${ }^{1}$, Vinícius do Nascimento Lampert ${ }^{2}$, Eduardo \\ Antunes Dias ${ }^{3}$, Gabriel Ribas Pereira ${ }^{4}$, Tamara Esteves de Oliveira ${ }^{4}$, Marcela Kuczynski da \\ Rocha $^{1}$, Júlio Otávio Jardim Barcellos ${ }^{1,4^{*}}$
}

\footnotetext{
${ }^{1}$ Universidade Federal do Rio Grande do Sul, Programa de Pós-graduação em Zootecnia, Porto Alegre, RS, Brazil.

${ }^{2}$ Embrapa Pecuária Sul, Bagé, RS, Brazil.

${ }^{3}$ Universidade Federal do Rio Grande, Instituto de Ciências Biológicas, São Lourenço do Sul, RS, Brazil.

${ }^{4}$ Universidade Federal do Rio Grande do Sul, Centro de Estudos e Pesquisas em Agronegócios, Porto Alegre, RS, Brazil.
}

\begin{abstract}
The objective of this study was to identify types of production system and their main indicators on bioeconomic efficiency, using qualitative and quantitative methods to evaluate beef cattle farms in the western region of the state of Rio Grande do Sul. A survey was carried out with 43 farmers operating in the western region of that state. All farms operated with complete cycle production systems in areas larger or equal to 900 ha. A qualitative questionnaire with binary answers and a quantitative questionnaire with numerical answers were applied. Technology and Management drivers were used for the calculation of the efficiency index of farmers obtained by both questionnaires. Farmers were divided into three clusters: low-efficiency level (LEL), intermediate-efficiency level (IEM), or high-efficiency level (HEL), as a result of the comparison of the scores obtained for the analyzed parameters. Subfactors resulting from each comparison (LEL $\times$ IEL; LEL $\times$ HEL, and IEL $\times$ HEL) were different as a function of the comparison and of the methods applied. Low-efficiency level farmers need to improve essential production processes, such as technology and management, as well as health management practices together with the financial management of the production system. Intermediate-efficiency level farmers need to improve their routine animal management, pasture management, and calculation of financial indicators to become highly efficient. The quantitative method allowed to identify underestimation $(39.3 \%)$ or overestimation $(24.2 \%)$ when farmers were are classified in clusters. Different methods may be used, but those based on quantitative information have stronger discrimination power to identify different types of farmers.
\end{abstract}

Key Words: beef cattle farmers, clusters analysis, efficiency, evaluation methods

\section{Introduction}

Technological innovations significantly changed beef cattle production and productivity in Brazil. During the last five years, soybean crop area increased $18.3 \%$ in the state of Rio Grande do Sul, particularly in the western regions, which concentrate $45 \%$ of the beef cattle herd of that state (IBGE, 2010). Soybean crop has expanded in this new agricultural frontier in areas planted in the past with rice in the summer, which were previously used for beef production

Received: March 19, 2016

Accepted: August 21, 2016

*Corresponding author: julio.barcellos@ufrgs.br

http://dx.doi.org/10.1590/S1806-92902017000100010

How to cite: Marques, P. R.; Peripolli, V.; Lampert, V. N.; Dias, E. A.; Pereira, G. R.; Oliveira, T. E.; Rocha, M. K. and Barcellos, J. O. J. 2017. A proposal for the evaluation of the bioeconomic efficiency of beef cattle production systems. Revista Brasileira de Zootecnia 46(1):65-71

Copyright (C) 2017 Sociedade Brasileira de Zootecnia. This is an Open Access article distributed under the terms of the Creative Commons Attribution License (http://creativecommons.org/licenses/by/4.0/), which permits unrestricted use, distribution, and reproduction in any medium, provided the original work is properly cited. or in areas that were exclusively used for grazing (Brandão et al., 2005; Lampert et al., 2012). This will demand further intensification of beef cattle production to achieve better bioeconomic efficiency.

The current bioeconomic efficiency indexes in Rio Grande do Sul are still low, despite some minor improvements obtained in the last decades. According to Anualpec (2010), from 25 surveyed locations in the city of Alegrete, there was a $1.6 \%$ profitability in breed-to-finish systems and grazing finishing systems (500 animal units, AU), which was lower than the Brazilian average (2.8\%). The production systems in the region presented $62 \%$ weaning rate, 35-month slaughter age, and 0.4 $\mathrm{AU} \mathrm{ha}^{-1}$ year pasturecarrying capacity compared with the Brazilian averages of $65.8 \%, 37.5$ months, and $0.67 \mathrm{AU}^{\mathrm{ha}} \mathrm{h}^{-1}$ year, respectively. The poor economic and production indexes demonstrate the low productivity and the frequent economic losses of the beef cattle business (Marques et al., 2011; Lampert et al., 2012).

The analysis of production systems is essential for decision-making and is aimed at determined strategies to be applied by farmers to obtain higher financial returns 
(Rosado Jr. and Lobato, 2010). Therefore, creating and evaluating methods that aid farm diagnosis is useful for the development and correct utilization of management tools (Abreu et al., 2006; Mosnier et al., 2009).

However, there is little information in literature on the development and comparison of different methods to evaluate the bioeconomic efficiency of beef cattle production systems. Simulations and development of conceptual and mathematical models are frequently used to evaluate the impacts of the application of determined technologies or of management interventions on the production system (Lamy et al., 2003; Tanure et al., 2013). Therefore, the objective is to identify system types and their main indicators on bioeconomic efficiency, using qualitative and quantitative methods to evaluate beef cattle farms in the western region of Rio Grande do Sul.

\section{Material and Methods}

This study was carried out in the western region of Rio Grande do Sul, Brazil (Figure 1), including eight cities that rear $90 \%$ of the regional beef cattle population. The farmers were interviewed in Alegrete, Santana do Livramento, São Gabriel, Rosário do Sul, Uruguaiana, Quaraí, Itaqui, and São Borja. A total of 43 farmers were interviewed between July and December, 2013. The included farms operated breed-to-finish systems and had a minimum area of 900 ha. Two questionnaires were applied to compare qualitative and quantitative methods to evaluate the efficiency of beef cattle production systems. Out of the initial sample, only 33 farmers were included in the analyses. The other 10 farmers were not evaluated because they did not maintain suitable data records.

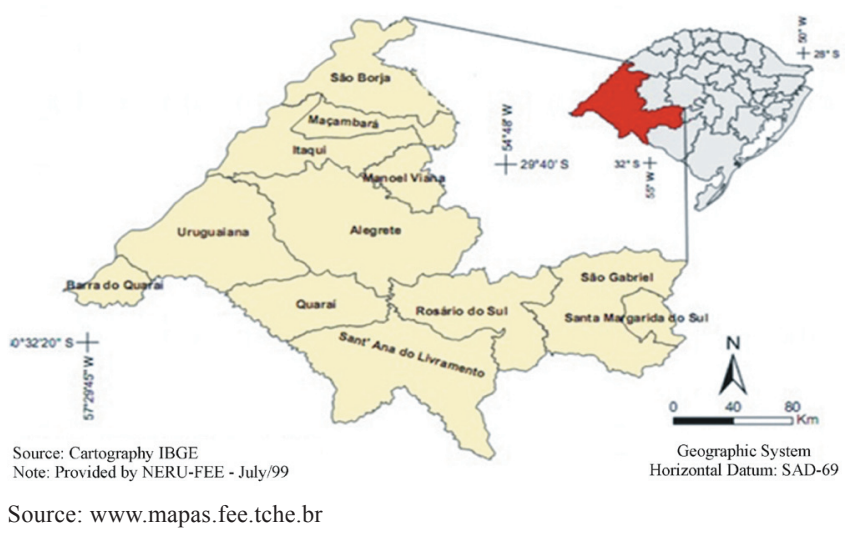

Figure 1- Location map of the surveyed cities.
The qualitative method applied the methodology of Marques et al. (2011), which assumes that drivers determine the efficiency of a production system whether the manager is able to control. Therefore, each driver was firstly classified as controllable, semi-controllable, or not controllable by experts that helped to develop the questionnaire. The present study, however, considered only two (technology and management) of the four drivers used by those authors. This choice was based on the power of influence the farmer had on the evaluated drivers. Drivers were then divided in subfactors, which were identified and analyzed in relation to the intensity of their favorable or unfavorable contribution for the efficiency of the system. Each factor was scored according to the results of the interviews of eight experts and to literature reviews. The final sum of the weight of subfactors of each driver was 1.0. Each driver was scored according to the level of influence on that driver. The weight of the subfactors was established by a panel with eight experts according to the degree of importance of the subfactor for the efficiency of a production system (Table 1).

Therefore, research steps were organized according to the following flow: drivers were divided into subfactors, which were identified and analyzed relative to the intensity of their favorable or unfavorable contribution for the efficiency of the system and each had a different weight. After the interviews, the status of each subfactor ranged from very unfavorable to very favorable.

Table 1 - Subfactors analyzed within each driver and their values, as determined by the qualitative method

\begin{tabular}{lc}
\hline Driver & Weight \\
\hline Technology & 0.50 \\
Suitability of a production system & 0.10 \\
Pasture quality, management, and species & 0.15 \\
Feed supplementation & 0.15 \\
Crop-animal production integration & 0.10 \\
Reproduction management & 0.10 \\
Herd genetics & 0.05 \\
Herd health & 0.15 \\
Production index records & 0.05 \\
Regular technical service & 0.10 \\
Routine animal management & 0.05 \\
& $\sum=1.00$ \\
Management & 0.50 \\
Labor training & 0.15 \\
Assets & 0.05 \\
Budget and cash flow & 0.10 \\
Strategic planning & 0.05 \\
Production costs control & 0.15 \\
Calculation of financial indicators & 0.10 \\
Herd identification & 0.10 \\
Sales & 0.10 \\
Use of information technology in the farm & 0.05 \\
Production scale & 0.15 \\
& $\sum=1.00$ \\
\hline
\end{tabular}


The questionnaire included four questions for each subfactor and the answers were considered positive or negative. The highest number of positive answers, the most favorable, is the contribution of the subfactor to business efficiency. The criteria to classify the answers and determine their acceptance percentage were: very favorable, four positive answers (100\%); favorable, three positive answers (75\%); neutral, two positive answers (50\%); unfavorable, one positive answer (25\%); and very unfavorable, no positive answer $(0 \%)$.

Based on the scores obtained in each subfactor, an efficiency index was created. Therefore, the efficiency index is composed of scores and weights of competitiveness drivers and subfactors. Technology and management driver evaluation is based on efficiency subfactors. Subfactor scores (SS) were calculated by multiplying the acceptance percentage (AP) of each answer by the weight attributed to each subfactor (SW) using the Equation 1:

$$
\mathrm{SS}=\mathrm{AP} \times \mathrm{SW}
$$

Driver score (DS) was calculated as the result of the division of the sum of subfactor scores (SFS) by the sum of subfactor weights (SW) multiplied by driver weights (DW) (Equation 2):

$$
\mathrm{DS}=\left[\left(\sum_{\mathrm{n}=1}^{\mathrm{n}} \mathrm{SS}_{\mathrm{n}}\right) / \sum_{\mathrm{n}=1}^{\mathrm{n}} \mathrm{SW}_{\mathrm{n}}\right] \mathrm{x} \mathrm{DW}
$$

The efficiency index was calculated as the sum of driver scores (Equation 3):

$$
\mathrm{EI}=\mathrm{DS}_{\text {technology }}+\mathrm{DS}_{\text {management }}
$$

Farmers were classified according to efficiency index as operating low, intermediate, and high efficiency (Table 2). The quantitative method was developed to evaluate the efficiency of production system using a questionnaire, whose questions required a numerical answer. The same drivers (technology and management) and subfactors used in the qualitative method were evaluated. Production and economic indexes frequently used in literature were applied to evaluate the efficiency of beef cattle production systems. The same team of experts that worked with the qualitative method helped to develop the quantitative method, with subfactors and their components within each driver (Table 3).

Table 2 - Level of efficiency of farmers according to the score obtained in the qualitative evaluation

\begin{tabular}{lcc}
\hline Status & Score & Level of efficiency \\
\hline Very unfavorable & $0.0-0.2$ & Low \\
Unfavorable & $0.21-0.4$ & \\
Neutral & $0.41-0.6$ & Intermediate \\
Favorable & $0.61-0.8$ & High \\
Very favorable & $0.81-1.0$ & \\
\hline
\end{tabular}

The quantitative questionnaire did not include predefined parameters to classify farmers in clusters according to the answers. Therefore, the parameters were developed after the questionnaires were applied. After the application of the questionnaire, production systems received a final score for each driver and related subfactors.

The final score attributed to each quantitative subfactor was calculated as the difference between the score given to the farmer by the minimum score obtained by all interviewed farmers, divided by the difference between the maximum and minimum scores, and the result was multiplied by 100 (Equation 4). This value defines the status of the farmer relative to the sample of farmers evaluated by the questionnaire.

Score $_{\text {final }}=\left(\right.$ Score $_{\text {Prod. System }}-$ Score $\left._{\text {Min }}\right) /\left(\right.$ Score $_{\text {Max }}-$ Score $\left._{\text {Min }}\right) \times 100$

The system evaluation methodologies were individually analyzed. Data were processed and statistically analyzed using the software SAS (Statistical Analysis System, version 9.3). The original parameters with less than $10 \%$ and more than $90 \%$ positive responses were removed from the analyses because they did not present statistical discrimination power. Therefore, only 17 parameters were analyzed. The ratio between farmers and drivers and subfactor was analyzed using multiple correspondence analysis.

Hierarchical cluster analysis was applied to the individual information of the farmers. The number of clusters was not pre-defined. Hierarchical cluster analysis clustered data sampled from groups of similar individuals and separated them into groups of farmers applying different production systems. In addition to the hierarchical cluster analysis, Ward's method was applied, as well as the squared Euclidean distance as a measure of similarity. The hierarchical cluster analysis identified the random formation of three clusters, designated as low-efficiency level (LEL), intermediate-efficiency level (IEL), and highefficiency level (HEL).

\section{Results}

The evaluated farms had an average area of 4.189 ha and an average cattle herd of 2.978 heads (Table 4). The efficiency differences among the farmers belonging to the clusters LEL, IEL, and HEL were determined by different subfactors, according to the method applied (Figure 2).

The comparison between LEL and HEL clusters by the qualitative method shows that LEL farmers need to improve their herd compared with HEL, as this was the only discriminating subfactor. The quantitative method allowed 
to identify underestimation $(39.3 \%)$ or overestimation $(24.2 \%)$ when farmers were classified in clusters. We observed that $63 \%$ of the interviewed farmers changed the efficiency of their beef cattle production systems when the quantitative method was applied, when compared with the qualitative method (Figure 3).

Table 3 - Components of each subfactor associated with the drivers technology and management used for the calculation of the efficiency index of farmers obtained by the quantitative questionnaire

\begin{tabular}{|c|c|}
\hline Technology & Management \\
\hline Suitability of the production system & Labor training \\
\hline $\begin{array}{l}\text { General stocking rate }\left(\mathrm{AU} \mathrm{ha}^{-1}\right) \\
\text { Age at } 1 \text { st mating (months) } \\
\text { Slaughter age (months) }\end{array}$ & Number of training courses per year \\
\hline Pasture & Asset control \\
\hline
\end{tabular}

Pasture stocking rate $\left(\mathrm{AU} \mathrm{ha}^{-1}\right)$

Soil chemical analyses

NPK applications/year $\left(\mathrm{kg} \mathrm{ha}^{-1}\right.$ year $\left.^{-1}\right)$

Rented area relative to total area (\%)

Pasture type (summer, winter, or winter/summer)

Animal inventory variation (last five years - $\mathrm{kg}$ )

Weight gain during grazing $\left(\mathrm{kg} \mathrm{d}^{-1}\right)$

Purchase of tractors and equipment (last five years - U)

\begin{tabular}{l} 
Supplementation \\
\hline Average daily gain during supplementation \\
Feeders area per head (cm head) \\
Supplement total digestible nutrients (\%) \\
Supplement crude protein (\%) \\
Productivity per area $\left(\mathrm{kg} \mathrm{ha}^{-1}\right.$ year $\left.^{-1}\right)$
\end{tabular}

Budget control

Frequency of flow cash evaluation (n)

Frequency of budgeting (n)

year

Reproduction

Cost control

Pregnancy rate (\%)

Birth rate (\%)

Abortion rate (\%)

Farm cost per ha per year (R\$)

Bull:cow (nc)

Cost per produced $\mathrm{kg}$ per year $(\mathrm{R} \$)$

Heifer body weight $30 \mathrm{~d}$ before mating $(\mathrm{kg})$

\begin{tabular}{|c|c|}
\hline Genetics & Calculation of financial indicators \\
\hline $\begin{array}{l}\text { Breeds used } \\
\text { Weaning body weight }(\mathrm{kg})\end{array}$ & $\begin{array}{l}\text { Gross margin per ha per year }\left(\mathrm{GM} \mathrm{ha}^{-1}\right)(\mathrm{R} \$) \\
\text { Total cost composition }\end{array}$ \\
\hline Health & Herd identification \\
\hline $\begin{array}{l}\text { Active principles used per year (n) } \\
\text { Overall mortality rate }(\%) \\
\text { Tick treatments per year (n) } \\
\text { Interval between tick treatments (d) } \\
\text { Mortality rate up to } 1 \text { year of age (\%) }\end{array}$ & $\begin{array}{l}\text { Ear tags used } \\
\text { Number of animal per year }(n)\end{array}$ \\
\hline Production index records & Marketing \\
\hline $\begin{array}{l}\text { Weight gain of the production system }\left(\mathrm{kg} \mathrm{d}^{-1}\right) \\
\text { System productivity }\left(\mathrm{kg} \mathrm{ha}^{-1} \mathrm{year}^{-1}\right) \\
\text { Offtake rate }(\%) \\
\text { Weaning rate }(\%)\end{array}$ & $\begin{array}{l}\text { Cull cow revenues }\left(\mathrm{R} \$ \mathrm{~kg}^{-1}\right) \\
\text { Steer revenues }\left(\mathrm{R} \$ \mathrm{~kg}^{-1}\right) \\
\text { Calf revenues }\left(\mathrm{R} \$ \mathrm{~kg}^{-1}\right)\end{array}$ \\
\hline Routine animal management & Use of information technology on the farm \\
\hline \multirow{3}{*}{$\begin{array}{l}\text { Annual weightings (n) } \\
\text { Carrying capacity assessments per year (n) } \\
\text { Endoparasite drenching per year (n) }\end{array}$} & How electronic spreadsheets are used \\
\hline & Production scale \\
\hline & $\begin{array}{l}\text { Gross margin per ha per year }\left(\mathrm{GM} \mathrm{ha}^{-1}\right)(\mathrm{R} \$) \\
\text { Number of animal heads/employee }\end{array}$ \\
\hline
\end{tabular}

$\mathrm{AU}$ - animal unit; nc - number of cows per bull; $\mathrm{n}$ - number of samples; $\mathrm{U}$ - units. 


\section{Discussion}

The main activity of most interviewed farmers is crop and beef cattle production (89\%) and their monthly family revenue is directly dependent on the efficiency of their production systems. Therefore, the areas and herds of the

Table 4 - Statistical description of the sample of interviewed farmers

\begin{tabular}{lccc}
\hline Item & Unit & Average & Standard deviation \\
\hline Farm area & ha & 4.189 & 3.429 \\
Cattle herd & $\mathrm{n}$ & 2.978 & 2.321 \\
Sheep herd & $\mathrm{n}$ & 781 & 1.250 \\
Crop area & ha & 940 & 1.520 \\
\hline
\end{tabular}

$\mathrm{n}$ - number of animals.

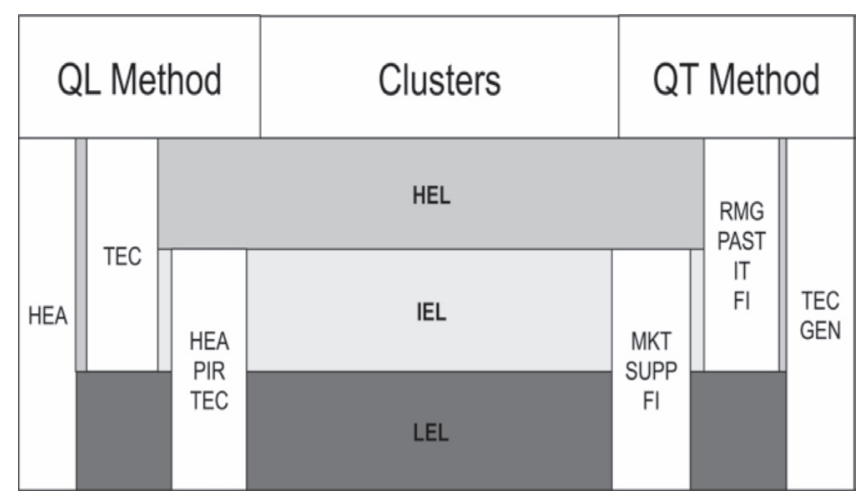

QL - qualitative method; QT - quantitative method; HEA - health; TEC - technology; PIR - production index records; HEL - high-efficiency level; IEL - intermediateefficiency level; LEL - low-efficiency level; MKT - marketing; SUPP supplementation; FI - financial indicators; RMG - routine animal management; PAST - pasture; IT - information technology; GEN - herd genetics.

Figure 2 - Cluster discriminant analysis as a function of efficiency level and evaluated method of the beef cattle production systems.

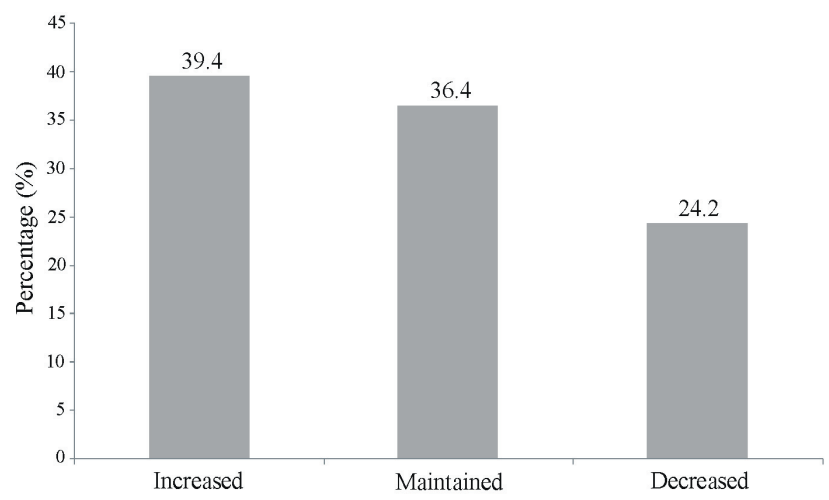

Figure 3 - Status migration levels of the farmers among clusters after the application of the quantitative method relative to the status obtained with the qualitative method. interviewed farmers is much higher than the averages in Rio Grande do Sul, categorizing them as large farmers. According to the study carried out in 2005, beef cattle farmers interviewed in the same area where the present study was performed owned, on average, 948.8 ha of land (SEBRAE/SENAR/FARSUL, 2005).

A questionnaire based on binary answers was performed in our study and the qualitative method indicates, in a more subjective manner, the factor (technology or management) that determines cluster formation. On the other hand, by using numerical answers, the quantitative method demonstrates more specific differences, identifying a larger number of subfactors involved in the classification of farmers into clusters. The qualitative method discriminated the IEL and LEL clusters by a set of subfactors, herd health management, and production index records. This set includes essential aspects of the production systems that may determine productivity (Beretta et al., 2002). This comparison indicates that the farmers in the LEL cluster need to improve the basic processes of their beef cattle production systems in order to achieve intermediate efficiency.

On the other hand, when using the quantitative method, the discriminating power was given by a single factor associated with the technology driver (feed supplementation) and two factors associated with management (marketing and financial indicators). This demonstrates the rationale that explains the higher efficiency of HEL production systems, which assumes that marketing and management based on financial indicators determined higher efficiency in the analyzed sample. However, these subfactors were not sufficient to differentiate IEL from LEL, as the use of feed supplementation, whose influences on productivity was determinant for the discrimination of these two clusters. The subfactor feed supplementation refers to the use of feed supplements and to associate characteristics, such as nutritional value, cattle management, and expected weight gain. Several authors have reported that the efficiency of feed supplementation depends on cost monitoring and on the forecast of financial results (Pilau et al., 2003; Figueiredo et al., 2007; Lampert et al., 2012).

The application of simple technologies, such as a defined breeding season, for instance, has a direct positive impact on the bioeconomic efficiency of breed-to-finish production systems (Abreu et al., 2003). In addition, production systems that apply technologies and manage them using production and economic indexes are more bioeconomically efficient (Oaigen et al., 2009). Therefore, the lack of production and financial control compromises the efficient use and management of the available technologies by the farmers in the LEL cluster. The higher discrimination power of 
the quantitative method is highlighted, as only the driver technology allowed differentiating clusters when the qualitative method was applied.

The IEL and HEL clusters were discriminated by the management of technologies available for beef cattle production (Technology). The quantitative method identified that the farmers in the HEL clusters performed routine animal management, such as weighing, pasture carrying capacity evaluation, and strategic drenching, as well as pasture management and calculation of financial indicators more efficiently than those in the IEL cluster. Therefore, the IEL farmers need to improve their routine animal management, pasture management, and calculation of financial indicators to become highly efficient.

Several studies in literature demonstrate that bioeconomically efficient systems apply technically suitable pasture management practices (Marques et al., 2011; Dill et al., 2015). In addition, as farmers in the IEL cluster do not calculate financial indicators, technologies such as nitrogen fertilization are not properly applied. Therefore, the absence of cost and flow cash control (financial indicators) compromises decision-making by the farmers relative to the technologies that directly affect the bioeconomic efficiency of the production systems (Johnson et al., 2010; Pruitt et al., 2012).

The results of the quantitative method indicate that LEL farmers need to improve their technology and to use breeds that are better adapted to the regional environment in relation to HEL farmers. This is an important strategy, based on a better interaction of the genotype with the rearing environment, which is represented by forage availability and quality, environmental temperature and humidity, solar radiation, and resistance to ectoparasites (Sonna et al., 2002; Nardone et al., 2010).

We emphasize that the qualitative method failed to determine the efficiency level of the production system because it did not agree with the quantitative method. This result is consistent with the findings of authors reporting that the use of qualitative methods entails subjectivity of the analyses, whereas the quantitative method is objective and developed to prevent analytical bias (Diehl and Tatim, 2004; Gioia et al., 2013).

When a questionnaire with close and classificatory answers is applied, some farmers tend be less committed during the interview. On the other hand, the quantitative method demands from the interviewee to take into account the sequence of questions to provide thoughtful, precise, and coherent answers. In addition, the technical knowledge of the farmers may contribute to overestimate the use of available technologies and may induce them to provide favorable answers to questions when the qualitative questionnaire is applied. Although in the present study farmers were reclassified by the quantitative method, which metrics are easy to validate, qualitative analyses are also useful because they allow a preliminary discrimination of farmers.

\section{Conclusions}

Applying methods to evaluate the efficiency of beef cattle production is an important approach to identify system types and their main indicators that allow their differentiation. Different methods may be used, but those based on quantitative information have stronger discrimination power to identify different types of farmers.

\section{Acknowledgments}

We thank the farmers and other agricultural professionals for providing key input when answering the questionnaires presented in this manuscript. We also acknowledge the funding from the Brazilian Council of Scientific and Technological Development (Project CNPq/ Universal no. 482423/2013-7) and the Coordination for the Improvement of Higher Education Personnel/CAPES, Brazil (Project CAPES/PNPD no. 2842/2010).

\section{References}

Abreu, U. G. P.; Lopes, P. S. and Batista, A. J. M. S. 2006. Avaliação da introdução de tecnologias no sistema de produção de gado de corte no Pantanal. Análise de eficiência. Revista Brasileira de Zootecnia 35:1245-1250. doi: 10.1590/S1516-35982006000400040.

Abreu, U. G. P.; Cezar, I. M. and Torres, R. A. 2003. Análise bioeconômica da introdução de período de monta em sistemas de produção de rebanhos de cria na região do Brasil Central. Revista Brasileira de Zootecnia 32:1198-1206. doi: 10.1590/S151635982003000500021.

ANUALPEC - Anuário da Pecuária Brasileira. 2010. AgraFNP, São Paulo.

Beretta, V.; Lobato, J. F. P. and Mielitz Netto, C. G. 2002. Produtividade e eficiência biológica de sistemas de produção de gado de corte de ciclo completo no Rio Grande de Sul. Revista Brasileira de Zootecnia 31:991-1001. doi: 10.1590/S1516-35982002000400023.

Brandão, A. S. P.; Rezende, G. C. and Costa Marques, R. W. 2005. Agricultural growth in the period 1999-2004, outburst in soybeans area and environmental impacts in Brazil. IPEA Discussion Paper No. 1062. doi: 10.2139/ssrn.660442.

Diehl, A. A. and Tatim, D. C. 2004. Pesquisa em ciências sociais aplicadas: métodos e técnicas. Prentice Hall, São Paulo.

Dill, M. D.; Pereira, G. R.; Costa, J. B. G.; Canellas, L. C.; Peripolli, V.; Neto, J. B.; Sant'Anna, D. M.; McManus, C. and Barcellos, J. O. J. 2015. Technologies that affect the weaning rate in beef cattle production systems. Tropical Animal Health and Production 47:1255-1260. doi: 10.1007/s11250-015-0856-x. 
Figueiredo, D. M.; Oliveira, A. S.; Sales, M. K. L.; Paulino, M. F. and Vale, S. M. L. R. 2007. Análise econômica de quatro estratégias de suplementação para recria e engorda de bovinos em sistema pastosuplemento. Revista Brasileira de Zootecnia 36:1443-1453. doi: 10.1590/S1516-35982007000600030

Gioia, D. A.; Corley, K. G. and Hamilton, A. L. 2013. Seeking qualitative rigor in inductive research: Notes on the Gioia methodology. Organizational Research Methods 16:15-31. doi: $10.1177 / 1094428112452151$.

IBGE - Instituto Brasileiro de Geografia Estatística. 2010. Estatística da produção pecuária: produção da pecuária municipal. Available at: <www.ibge.gov.br/estadosat/>. Accessed on: Mar. 21, 2016.

Johnson, R. J.; Doye, D.; Lalman, D. L.; Peel, D. S.; Raper, K. C. and Chung, C. 2010. Factors affecting adoption of recommended management practices in stocker cattle production. Journal of Agricultural Applied Economics 42:15-30. doi: 10.1017/S1074070800003266.

Lamy, V. C.; Recalde, M. and Barraud, A. 2003. The competitiveness of the beef sector in Argentina and Canada. Agricultural and AgriFood Canada. Available at: <http://ageconsearch.umn.edu/handle/ 53768>. Accessed on: Mar. 21, 2016.

Lampert, V. N.; Barcellos, J. O. J.; Kliemann Neto, F. J.; Canellas, L. C.; Dill, M. D. and Canozzi, M. E. A. 2012. Development and application of a bioeconomic efficiency index for beef cattle production in Rio Grande do Sul, Brazil. Revista Brasileira de Zootecnia 41:775-782. doi: 10.1590/S1516-35982012000300042.

Marques, P. R.; Barcellos, J. O. J.; McManus, C.; Oaigen, R. P.; Collares, F. C.; Canozzi, M. E. A. and Lampert, V. N. 2011. Competitiveness of beef farming in Rio Grande do Sul State, Brazil. Agricultural Systems 104:689-693. doi: 10.1016/j.agsy.2011.08.002.

Mosnier, C.; Agabriel, J.; Lherm, M. and Reynaud, A. 2009. A dynamic bio-economic model to simulate optimal adjustments of suckler cow farm management to production and market shocks in France. Agricultural Systems 102:77-88. doi: 10.1016/ j.agsy.2009.07.003.
Nardone, A.; Ronchi, B.; Lacetera, N.; Ranieri, M.S. and Bernabucci, U. 2010. Effects of climate changes on animal production and sustainability of livestock systems. Livestock Science 130:57-69. doi: 10.1016/j.livsci.2010.02.011.

Oaigen, R. P.; Barcellos, J. O. J.; Christofari, L. F.; Braccini Neto, J.; Oliveira, T. E. and Prates, E. R. 2009. Análise da sensibilidade da metodologia dos centros de custos mediante a introdução de tecnologias em um sistema de produção de cria. Revista Brasileira de Zootecnia 38:1155-1162. doi: 10.1590/S151635982009000600025.

Pilau, A.; Rocha, M. G. and Santos, D. T. 2003. Análise econômica de sistemas de produção para recria de bezerras de corte. Revista Brasileira de Zootecnia 32:966-976. doi: 10.1590/S151635982003000400024 .

Pruitt, J. R.; Gillespie, J. M. and Nehring, R. F. 2012. Adoption of technology, management practices, and production systems by U.S. beef cow-calf producers. Journal of Agricultural Applied Economics 44:203-222. doi: 10.1017/S1074070800000274.

Rosado Jr., A. G. and Lobato, J. F. P. 2010. Implementation of a performance indicators system in a beef cattle company. Revista Brasileira de Zootecnia 39:1372-1380. doi: 10.1590/S151635982010000600029 .

SEBRAE/SENAR/FARSUL. 2005. Diagnóstico de sistemas de produção de bovinocultura de corte no estado do Rio Grande do Sul. Relatório. SENAR, Porto Alegre, RS.

Sonna, L. A.; Fujita, J.; Gaffin, S. L. and Lilly, C. M. 2002. Molecular biology of thermoregulation. Invited review: effects of heat and cold stress on mammalian gene expression. Journal of Applied Physiology 92:1725-1742. doi: 10.1152/japplphysiol.01143.2001.

Tanure, S.; Nabinger, C. and Becker, J. L. 2013. Bioeconomic model of decision support system for farm management. Part I: Systemic conceptual modeling. Agricultural Systems 115:104-116. doi: 10.1016/j.agsy.2012.08.008. 